\title{
Corporate Community Crisis in Nigeria; Causes and Consequences- Case Study Of Presco Industries Ltd and Oghareki Community.
}

\author{
Dr Iyoha Osaretin
}

\begin{abstract}
So long as human beings live together and pursue different goals in the same environment, conflict of interest must arise. The inability to manage conflict is the cause of crisis. While conflict is sometimes desirable for a state of equilibrium and positive change to occur in the society, crisis is undesirable because it brings about destruction, which could have been avoided by dialogue. Thus dialogue is a necessary tool for crisis management. The main concern of an arbitrator in crisis management is peace. In doing this, parties to a crisis assist the arbitrating panel in determining the causes of the crisis, adequate compensation for victims and recommendation of measures for lasting peace. Examples are Federal Government of Nigeria versus NigerDelta Militants and the Citizens of Nigeria, Michelin industries Plc versus Udo community in Edo State, Oghareki community versus Presco Industries Ltd in Delta State and the Ogonis versus Shell Development Co. Plc in Rivers State. These crises ended on a dialogue table. A case study is Oghareki Community and Presco Industries Ltd where 100 persons from disagreeing parties were randomly selected. Their responses to a set of questions were analysed and discussed. The result showed that the parties had mutual interest for peace.
\end{abstract}

\section{Definition and causes of crises:}

\section{Introduction}

Crisis can be defined as a state of continuous disagreement that can lead to calamity if not immediately resolved between the disagreeing parties. According to Longman Family Dictionary $(1989: 162)^{1}$ crisis means "an unstable situation, a sudden attack of pain or distress". This definition by interpretation means that crisis can be spontaneous. It can be painful because it can cause an inestimable damage to the parties involved and to neighbourhood by extension.

Bednar (2006:454) $)^{2}$ defined crisis as "the interaction of interdependent people or groups with perceived incompatible goals..." This definition recognizes the fact that human beings are dependent on each other, but in the process of pursuing personal goals, disagreement may occur. When the disagreement persists for too long, crisis begins. Crisis therefore is a dynamic interactive process caused by unsettled conflict of the dependency of human beings involved while pursuing some personal interests or values.

Ogbeide (1998:53) $)^{3}$ defined crisis from the industrial or organization point of view. To him industrial crisis is a disagreement arising out of the divergent interpretations of labour contract of agreement between employees and employers or labour union and the management. Such a conflict usually centres on working conditions in terms of wages, hours of work, safety, pension, fringe benefit, and so on. Similarly, corporate community conflict is the dispute or disagreement that arises between organization and the people (local community) due to the struggle for some unmet needs such as failure to provide good roads, schools, electricity and health facilities, or a misconceptions arising from an implementation of an earlier agreement.

\section{Statement of problem}

These authors have witnessed the consequences of some conflict situations that eventually resulted to great crisis. In their opinion, these crises were preventable, but they were not well managed. The crisis resulted to losses, which were counted in millions of naira, while some of the losses were irredeemable. This precisely was also the case of the crisis between Oghareki community and Presco Industries Ltd. The causes were due to some immediate and long term disputes relating to tenure disagreement and failure of the corporate organization to live up to her social responsibility as expected by the youths and elders of the community. That these disagreements could lead to crisis and that peace was not negotiated before the crisis escalated are of concern to this author. Why must disagreement be allowed to degenerate to crisis? What are the consequences of such crisis and how can these be prevented? These are the crux of this study titled corporate community crisis in Nigeria, causes and consequences. 


\section{Consequences of Corporate Community Crisis.}

\section{Corporate Community crisis may lead to large scale looting and destruction of property}

Sociologists have opined that crisis is bad to the nation, the community, the family and even the individuals who are involved directly, and those involved indirectly. Crisis they said, results to so many evils; from as small as fighting, inflicting injuries to selves to as big as capital losses like killing of human beings, burning down of hamlets, villages and buildings. When it is between a community and her guest organization, the latter is perpetually put in great jeopardy. The organization is always on the receiving end and unable to fight back. This is because the organization is a total stranger to the host community; the staffs working in the organization are often members of the aggressive community and at the end of the crisis the organization still hopes to continue staying and working in the community. Even when some staffs of the organization who are also members of the host community conduct themselves in a manner capable of earning them dismissal letters, the organization under the guise of making peace will continue to accommodate them as staffs. When an organization finds itself in this kind of predicament, it becomes compelling for her to seek for opportunity to dialogue with stakeholders. It is therefore recommended that rather than war-war, you should jaw-jaw. This was the case between Michelin industries Plc and Udo community in Edo State, Oghareki and Presco Industries Ltd in Delta State and the Ogonis and Shell Development Co. Plc in Rivers State.

According to Ronsogbe consultancy services $(1998: 28)^{4}$, intra or inter communal conflict if not properly controlled could result to crisis in which case the people concerned could start killing themselves, destroying property and looting. This struggle can last for a long period of time and in this way depriving the communities involved of any progressive attainment.

\section{Communal crisis may lead to national and international war:}

Before 1999, oil derivation formula was zero. That is, no special fund was set aside for the development of the oil producing communities. Suddenly the people awoke from slumber and began to ask for a fair share of the oil revenue. According to Prime News-line (Jan/Feb. 1999) ${ }^{5}$, the picture of the sufferings of the Niger-Delta people can be painted like this: A man lives in the middle of a river, but is hungry and thirsty most of the time. Despite the vast stretch of water all around him, he can't find a cup of water to drink, because he is not permitted to drink the water. The river, he is told belongs to the community.

"It is unacceptable the way things have happened. I have vowed to stop the rot. There has been injustice but should we throw away the baby with the bath water? "

Writing under the topic "Deprivation is the Root of Our Tragedy" Chief Zimughan (1999:31-33) ${ }^{6}$ an Ijaw leader stated that what is causing the youth's restiveness is the total neglect of the communities that are producing oil in the Niger Delta. The youths are agitating for a fair share and of course recognition by the Federal Government and the oil companies that tap the resources in the Niger-Delta. He declared:

"People may think the youths are reactionary or that it is youthful exuberance. But the fact is that the youths have become aware of their rights. Rights could be social, economic or legal. But we now find ourselves in a Federal structure where there are certain legislations that are quite oppressive.

According to Hassan Tai Ejibunu (2007) ${ }^{7}$, the crisis portends a very grave danger for the Niger Delta Region in particular and the Nigerian State in general. The truth of the matter is that the militants are not only confronting the Nigerian state, they are also at war with an extension of global capitalism represented in the region by the multinational oil companies. The situation, if not curtailed, could lead to a serious war between the armed militants and the Federal Government of Nigeria. We should not forget in a hurry that at some point in time, the whole of South-south and South east threatened to join forces to pull out of the Federal arrangement. The Yoruba nations joined to call for the balkanization of Nigeria. All these groups were represented by their own native forces or militia, for example, the Igbos called their own formations Bakasi and MASORB (movement for the actualization of the sovereign republic of Biafra), the Niger Delta Called their own Niger-Delta Militants and the Yoruba tribe called their own Egbesu and the Oduduwa Pressure Group.

\section{Corporate communal crisis hinders development}

There is usually no economic development in an environment bedevilled with crisis because no sane investor would like to risk his capital in a place where the safety of the plants and machineries are not guaranteed and the workers cannot go to work. For the long period of the Niger-Delta crisis, there was no development taking place in the region, especially the Ogoni land. Since after peace returned, great infrastructural changes have come to stay. There are now new schools, roads, bridges, light and portable water and these and many more are still in progress.

Ronsogbe consultancy services (ibid p49) ${ }^{8}$ argued that the level of development obtained in a local government will depend most importantly on the level of stability, which is desirable from the capacity of the local government administration to manage conflict occurring within the Local Government Area. He discussed two kinds of communal conflict: intra and inter communal conflict. He opined that intra communal conflict 
would result from disagreement over the misuse of property jointly owned by members of one community for example farmland, fishing pond, etc. But inter communal conflict is the disagreement between two separate communities resulting from the struggle to dispossess one another of a particular property, e.g. piece of land, control of a shrine, and the location of an institution by government.

\section{Crisis may resort to long lasting peace.}

Crisis may have its positive face, as not all crisis that yield more losses than gain. Some crises have given rise to positive policy changes resulting to improved quality live for the people that were involved. Peil $(1977: 346)^{9}$ reported the case of the Agbekoya Revolution involving the farmers in Western States of Southern Nigeria in 1970. The team of the revolution was "Farmers are suffering". According to Peil.

"The impetus was a rise in taxation and arrest of defaulters coupled with a price for cocoa which was far below the world cocoa price at the time. The farmers tried to air their grievances through peaceful channels, but the bureaucrats in the capital refused to listen. Populist leader then organized open conflict..."

Attempt to restore peace involved police action, the appointment of a commission of inquiry, and announcement by government calling for peace. Peace was resorted, but after six months government did nothonour its pledge. New attempts were made to collect taxes and this brought another disturbance now on a wider scale. This led to the breaking of Ibadan jail and prisoners released. Government immediately reacted by withdrawing their tax officers, lowering taxes and releasing Agbekoya protesters who were detained on grounds of murder. The rebellion stopped. The point here is that dialogue, compromise and concession are necessary sometimes in order to gain peace. A change was desired but it was not to come so easily without violence since the authorities who ought to grant the change did not seem bothered by the people's desire. In other words, when dialogue, compromise and concession fail then violence takes precedence.

In January 2012, the Federal Government of Nigeria attempted to totally withdraw the subsidy on petroleum products, which would have meant that a litre of petrol would cost N150.00. Organized labour resisted it leading to a total industrial action in all the public and private sectors of the economy. The legislative arm of government issued an ultimatum calling on the Presidency to withdraw its pronouncement by reverting petrol prize to the former N65.00 per litre. This immediately led to series of negotiation meetings between the organized labour representatives, the legislature and the presidency. The outcome was favourable to both parties. The federal government got a marginal N32.00 increase in the petrol pump price bringing the price of petrol to N97.00 per litre. The general public gained by way of promises for better life and job creation for the teaming unemployed youths. A committee was set up to manage the oil subsidy withdrawal savings described as the "oil subsidy reinvestment fund committee" under the Chairmanship of Chief Christopher Kolade. Probe panel was set up by the House of Representative under the Chairmanship of Hon Faruk Lawal to investigate what the presidency described as the "Cabal in the oil industry ". All these brought some measure of sanity into the oil subsidy business, because as it now stands, the Federal Government, the Oil Magnets and the Nigerian Citizens have reached a tentative compromise.

The long crisis on oil exploitation principles between the South-south youth and the Federal Government of Nigeria, which led to the shutting down of so many oil wells and the kidnapping of oil company workers, especially the expatriates, led to the establishment of the Niger-Delta Development Commission and the constitutionalization of the $13 \%$ derivation formula. In addition, this led to the amnesty policy, which brought thousands of the youths to negotiate with the federal government. Those who accepted the amnesty policy were given scholarship to lean trade and to go to the University for Various Courses overseas. Today, development has started to enter the South-south regions and the youths getting employment in the oil prospecting, oil exploiting and oil marketing companies all around the region.

\section{Objectives Of The Study:}

This study therefore seek to examine the following:

The causes of corporate community crisis in Nigeria.

The consequences of such crisis.

Strategies adopted in resolve such corporate community crisis.

Presco Industries Ltd and Oghareki Community crisis as case study.

With particular reference to the crisis between Presco Industries Ltd and Oghareki community in Delta State, the root causes are far reaching. The genesis of the crisis can be traced to the contractual agreement between the company and Oghareki community.

According to the agreement of transference of possession of land $\left(19^{\text {th }}\right.$ January, 1998) the community initially leased the land to the United African Company Ltd for a term of 99 years commencing from the $5^{\text {th }}$ day of September 1936. United African Company Ltd planted on the land palm oil trees and built houses for 
accommodation of employees, offices and mills for extracting oil from palm oil fruits. On $5^{\text {th }}$ May, 1954, United African Company transferred the plantation and all its estate to Pamol Ltd (OPC) without the information and consent of the landlord and transferors of the land. The community therefore contested the transfer deal by Pamol Ltd and took possession of the land for lease to another company for the remaining part of the contract agreement it entered into with United African Company in 1936.

The remaining period of 37 years left unexpired under the lease of $9^{\text {th }}$ June, for the estate and plantation was transferred to Presco Industries Ltd with effect from $1^{\text {st }}$ February 1996 subject to "the terms of that lease and to terms additional to or repeating those terms excepting the provision relating to payment of rent by the Oghareki community" (Deed of Transfer 1998) ${ }^{10}$.

\section{The Conditions for Transfer}

1. To pay the consideration money of N1, 000,000.00 (one million naira) in advance in every January of each Year commencing from the $1^{\text {st }}$ day of January, 1998 in addition to a sum of N100, 000.00 (one hundred thousand naira) as consideration for the forfeiture of the fishing right on the property by the transferors.

2. To erect on the land buildings for residential accommodation for employees, offices, and factories for extraction of oil from palm oil fruits and to carry on the trade of palm oil and palm kernels.

3. Not to assign or subject or underlet or part with possession of all or any part of the land without first obtaining the consent of the transferors in writing.

4. That if the transferees shall carry on any other trade on the land in their name or in any other name, the transferees shall first surrender possession to the transferors by deed.

Provided always and it is hereby agreed as follows:

a). That if the consideration money hereby reserved shall be in arrears for three months the Transferors shall re-enter and retake possession as if the term has not been granted whether or not formally demanded subject to the right of the Transferors for arrears of the consideration money.

b). That if the agreement shall be caused to determine by whatever event the Transferees shall remove from the Land their buildings or structures or any other thing constructed on the Land for the purpose of their trade provided that in the process or course of removal no harm or damage shall be caused to any person.

c). That the Transferees shall award at their discretion a number of four scholarships at any given time to Oghareki natives to study Agronomy, or Agricultural Economics or Accountancy or Engineering and eventually on completion of studies to serve the Transferees.

d). That the Transferees shall assist in keeping the roads in good State or repairs.

e). That the Transferees shall give employment to a fair number of natives of Oghareki commensurate with the required qualifications.

f). That the Transferees shall contribute to the development of Oghareki community.

g). The Transferees shall contribute N100, 000.00 annually towards the Festival of Oghareki.

h). That the Transferees shall make available annually an amount for the maintenance of the palace of the Ovie of Oghara.

i). That Transferor shall make available an additional area of land of not less than 2,500 hectare on the Eastern and Western boundaries of the existing property on the condition that the transferees shall pay to the rightful owners compensation for economic trees as per Government of Delta State rates and increase the amount due to the Transferors on a pro-rata basis. ${ }^{1}$

When the youths felt that the terms of the contract were no longer followed by Presco Industries Ltd especially as it relates to employment and financial returns, they issued a number of threats and eventually attacked Presco, looting and destroying properties. This led to the disruption of oil business operations of the company until a peace committee was set up. The proposal made by the committee, seem to be the basis for the present industrial harmony. But it is a time bomb that will explode again except something is done and urgently too. The exploration of what should be done is therefore the basis for the study.

The presco industries and oghareki youth crisis:

Below is the extract from security report of the true consequences of the crisis situation between the community youth and the company.

Mill-gate was locked-up,

Archibong Patrick was attacked and injured.

Plantation Workers were threatened.

Criminal cases of vandalization, stealing and looting were reported and arrests made.

Several proposed Attacks were averted.

Security men were attack and wounded.

Planned armed robbery took place.

The youths and women of Oghara within Urhobo quarters Ajagbodudu demonstration. 
The presco industries crisis revisited:

On $19^{\text {th }}$ February, 1999 the management of Presco Industries met with Oghareki youths representatives to review the situation. The community leader made a number of demands as follows:

Grading of the road

Granting of fishing rights

Upgrading the schools at Oghareki

Employment of Oghareki youth to management position.

On $24^{\text {th }}$ March, 1999 Presco Industries received a letter from Oghareki community solicitors alleging that a key condition for the lease of the land occupied by Presco has been violated by Presco Industries by refusing to employ natives to work in the company. They warned that refusal to meet to resolve this would lead to break down of "law and order in the area"

\section{Methodology}

Study design: The study was designed to ascertain the causes and consequences of corporate community crisis in Nigeria, using Oghareki and Presco Industries Ltd as reference point. Both quantitative and qualitative study methods were used to collect and analyse data as the study was classified as an analytical study.

The people resident in Oghareki community and the workers of Presco Industries Ltd were the target respondents. Eligibility was defined as adults that were resident in the community for one year or more, and workers who have been in employment of Presco Industries Ltd for one year and above. Respondents were stratified into three groups as follows:

Selected leaders of thought in Oghareki community. They were made up of community heads, opinion leaders and age group leaders. They were targets because they played key parts in planning crisis and peace strategies.

General public of Oghareki aged 18 years to 60 years. The general public was targets because they received the impact of the crisis directly. In terms of the consequences of the crisis the public were in the position to tell the tale.

Presco management and staff were target respondents because they represented the peace negotiators and who also received the complaint of the community.

All interviews were restricted to the residents of Oghareki community and workers of the industry. As a small scale study, a sample size of 100 respondents was distributed among the three strata of respondents in the following order:

\section{Sampling technique:}

Two kinds of sampling techniques were used to reach the study elements (probability and nonprobability).Purposive sampling method (non-probability sampling) using a snowballing approach was used to select the representatives of leaders of thought from within the concerned communities and Presco management. An in-depth interview was conducted with each identified community leader and Presco Management Staff. The general public respondents and the line staff of Presco were selected using a probability sampling methods. Their interview was household based. The questionnaire contained both open and closed-ended questions. The data collected was properly coded, edited and collated electronically using the SPSS.

\section{Data Analysis:}

The distribution of respondents is as shown in the table below: Majority $(80 \%)$ of the respondents were males and only $20 \%$ were females.

By random selection, bulks ( $70 \%)$ of the respondent were selected from the youths (26-45 yrs), $20 \%$ came from $45-55$ yrs and only $10 \%$ came from the old age of 56 yrs and above. This agrees with the demographic tradition of the older the fewer in the population.

About one third $(30 \%)$ of the respondents were traders, one quarter $(25 \%)$ were teachers and about one tenth $(12 \%)$ were farm supervisor.

As expected, the Urhobos formed a bulk (40\%) of the respondents both from PRESCO and from the host community. Surprisingly, the Igbos formed $20 \%$ of the total respondents. These were a mixture of people from Imo state, Delta and Anambra states respectively. The Bini, Esan and Owan formed the next significant population of respondents with $10 \%, 9 \%$ and $8 \%$ contribution respectively.

Majority (60\%) of the respondents were married, $23 \%$ were single (that is, never tested marriage) and $10 \%$ were divorced. The divorce rate is quite high; unfortunately the study did not explore reasons for the high incidence of divorce. Although experience showed that a lot of strangers from neighbouring towns and villages who came to settle to seek for better life through trading and seeking for company contracts especially the female population were people who have had problems with their marriages or homes and therefore decided to seek an 
alternative place for shelter. About 7\% (separated 5\% and widowed 2\%) of the respondents were potential fun seeking population.

Quite unlike a rural setting, all the respondents were literate. Majority (35\%) had post-Secondary school education, that is, NEC, TC II, HND, etc $29 \%$ and $20 \%$ had the senior secondary school and the Junior Secondary School education respectively. A significant population (16\%) claimed to be at least a first degree/HND holder that is including those with masters' degree and postgraduate Diploma.

Amongst the reasons given for the cause of the crisis, $36 \%$ claim "Oghareki youths wanted to be employed by Presco into management position". $24 \%$ said it was cause by "poor information management" and another $20 \%$ claim "PRESCO workers were not respecting the norms and value of Oghareki people", for example denying the people fishing right in the pond inside PRESCO Industries Ltd.

Other reason given that caused the crisis included "poor communication between the community and PRESCO" $(30 \%)$.The people lamented that the crisis had different degree of effects on both the native and the strangers' resident inside PRESCO Estate and Oghareki community.

Among the effect mentioned include "made some people homeless" $(25 \%)$ and

"send so many people parking out of the community" (20\%).

The people were full of praises for the parties that made peace. Among those parties mentioned included the "Youth leaders, Ovie of Oghareki, Managing Director of PRESCO and his men and Nigeria Police Force."(47\%).

Half $(50 \%)$ of the respondents claimed that peace was achieved because "the community demands were negotiated, an agreement was reached". And another 45\% mentioned that "Presco gave job to some qualified youths in the community". $70 \%$ of all the respondents gave credit to the strategy adopted to achieve peace. These group of respondents claimed that the strategy adopted was "Effective", and 15\% added that the strategy was "very effective".

\section{Likely Causes of future Crisis:}

$42 \%$ of the respondents claimed that the crisis might reoccur "if Presco stops to employ Oghareki youths on their demand" and $25 \%$ claimed it would reoccur "if Presco fails to accept the demands of the workers who are made up of mainly Oghareki indigenes. Therefore to maintain peace for a long time, there should be a continuous dialogue between the two parties (44\%) and Presco must continue to employ Oghareki youths $(56 \%)$.

\section{Summary Of Main Findings, Recommendation And Conclusions Summary of main Findings:}

The immediate causes of the crisis were enumerated to include "Oghareki youths wanted to be employed by Presco into management position (36\%) and poor information management (24\%). They claimed that the consequences of the crisis include "made some people homeless" $(25 \%)$, "sent so many people packing out of the community" (20\%).

Half of the respondents described the strategy adopted to achieve peace as a joint meeting of the youth's leaders, the Ovie of Oghareki, Presco management and the Nigerian Police representative. They agree that this strategy was very effective.

However, they opined that the crisis might reoccur if Presco fails to adhere strictly to the peace agreement; ensuring that Oghareki youths are given jobs of management level, that the Ovie is given his due royalty and that the people of Oghareki get access to their fishing pond inside Presco estate. If these conditions are fulfilled then relative peace would be sustained for a long time.

\section{Recommendation:}

For the purpose of emphasis it is hereby itemized as follows:

Corporate organizations should consider employing qualified persons in their host communities. The outcome of the study showed that the crisis came because the youths of Oghareki were denied employment to management positions in Presco industry. It is therefore advised that Presco should endeavour to fulfil this aspect of the community desire.

Corporate organization should discharge some social responsibility to their host community. The request for scholarship to be awarded to the intelligent members of Oghareki community is one way to satisfy this social responsibility. There should be clear guidelines for giving scholarships and only those who satisfy the condition would benefit. 
It is also advantageous to the company in the sense that some of these scholarship beneficiaries would come back to become managers at Presco. They would be in a better position to understand that the goose which lay the golden egg must not be killed. For this reason they would do everything to ensure the continuous survival of Presco Industries Ltd. As managers and members of the community, it will become easier for Presco to negotiate for more land for future expansion.

The request for permission to fish in their pond is also in order. The only condition is that the security of Presco property would be negotiated in the process. The community would guaranty this.

The Ovie needs to be assisted to maintain his palace. A fixed annual honorarium should be paid to him as the symbol of the people's authority.

Corporate organization should identify with the infrastructural development of its host community. Such physical development would always be used by Presco as a reference monument and as a bet to negotiate for favour from the community when need be.

\section{Conclusion}

Crisis can be spontaneous in nature. It can be caused by an unsettled conflict. It can also be caused by the struggle for social amenities. In all these, early intervention is the good way to avert crisis.

Corporate Community crisis can lead to large scale looting and destruction of property. It can hinder Communal development. It can prevent the growth of commercial organizations and stop commerce in a community. However, Crisis may resort to long lasting peace if the purpose is focused and settlement process well negotiated.

Therefore, while we agree that crisis is bad, it can also bring about negotiated peace. Crisis sometimes bring about a shift in the balance of power or equilibrium.

Marx Weber argued that without crisis the landlords (haves) would continue to oppress the labourers (have not). In order words, where peaceful negotiation fails, crisis becomes a means of putting a stop to management's oppression of the workers in a corporate organization and by extension the people and the government. He further postulated that without class consciousness there would not be group cohesion to bring about the desired evolution. Therefore, the protectorate or the oppressed need to recognize the fact that they are oppressed before they can fight back as one united force.

This is the case with Oghareki community (oppressed) and Presco (oppressor). The youths realizing the level of oppression they are passing through protested and became violent when it became clear that mere protest could bring about no change. The violence brought about the desired change peace returned.

It is hoped that the policy recommendation in this study would be implemented by the concerned authorities for a lasting peace to be sustained.

[1]. Longman Family Dictionary $(1989: 162)^{1}$

[2]. Ronald H. Tuschl, and Hassan Tai Ejibunu (2007), Nigeria's Niger-Delta Crisis: Root Causes of Peacelessness.http://epu.ac.at/fileadmin/downloads/research/rp_0707.pdf

[3]. Uyi - Ekpen Ogbeide. Conflict Resolution in Community Project Execution. As part of seminar presented to senior staff of NNPC workers in 1998 by Ronsogbe consultancy services. Benin City. P. 40.

[4]. Prime Newsline Jan/Feb. 1999and This Day News Paper13 ${ }^{\text {th }}$ June 1999.

[5]. Andre Gunder Frank: The development of underdevelopment in James D. Cockcroft et al. Dependence and underdevelopment Latin America's Political Economy, Anchor Books New York.

[6]. Chief Zimugha F."Deprivation is the Root of Our Tragedy" in Prime Newsline, Vol. 1 No 2. (1998)

[7]. Ely Chinoy Society; An introduction to Sociology. (1967) New York, Random House.

[8]. Efurhievwe (1999) "Letter to the Chairman of Ethiope West Local Govt. Area by Oghara Solicitors. Unpublished copy by Presco Secretariat.

[9]. Flippo Personnel Management McGraw-Hill Book Co. Japan. (1980) Series, McGraw Hill Block Co. Japan.

[10]. Olusola Oke "Memorandum Submitted to the Judicial Commission of Inquiry into the communal crisis in the Riverine Area of Ondo State". Newsline Publication 1998 P.1

[11]. Julius Ihonvbere ed.): Political Economy of Crisis and underdevelopment in Africa. Selected Works of Ake (Lagos) JAD Publishers, 1989.

[12]. Koontz H \& Essential of Management McGraw-HILL Inco. N.YO’Donnell C (1978).

[13]. Peil M.Consensus and conflict in African Societies. An introduction to Sociology (1975) Longman Group Ltd Great Britain.

[14]. Peter M. Blau Formal Organization \& W. Richard Scot San Francisco Chandler. (1962).

[15]. Presco "Minutes of management and community meetings. (1998) Unpublished meeting proceeding by Presco Secretariat.

[16]. Ubeku A. K. Personnel Management in Nigeria, (1975) Ethiope Corporation, Benin City, Nigeria.

[17]. Presco "Security reports on the Estate security situation" (1999) Unpublished secret information. 


\section{APPENDIX}

TABLE 1: No. of Respondents interviewed

\begin{tabular}{|l|l|l|l|l|}
\hline Respondents & Oghareki & Presco & Total & Type of interview. \\
\hline Leaders of thought/elders & 10 & - & 10 & IDI \\
\hline Presco Management & - & 10 & 10 & IDI \\
\hline Oghareki youth leaders and general public & 60 & - & 60 & $\begin{array}{l}\text { Structured } \\
\text { interview. }\end{array}$ \\
\hline Presco staff & - & 20 & 20 & Structured interview \\
\hline
\end{tabular}

TABLE 2: Causes of the Crisis identified

\begin{tabular}{|l|l|l|}
\hline Response & Frequency & \% \\
\hline $\begin{array}{l}\text { Oghareki Youth wanted to be employed by PRESCO into management } \\
\text { position }\end{array}$ & 90 & 36 \\
\hline $\begin{array}{l}\text { Presco management was not keeping the term of constract with the } \\
\text { community }\end{array}$ & 20 & 8 \\
\hline $\begin{array}{l}\text { Presco workers were not respecting the norm and values of Oghareki } \\
\text { people e.g. denying the fishing right }\end{array}$ & 48 & 20 \\
\hline Poor information management & 60 & 24 \\
\hline Power struggle among the elders of Oghareki people & 30 & 12 \\
\hline Total & 248 & 100 \\
\hline
\end{tabular}

TABLE 3: Other factors causing conflict

\begin{tabular}{|l|l|l|}
\hline Response & Frequency & $\mathbf{\%}$ \\
\hline Recognition of the Itsekiris as Co-Landlord of the estate. & 80 & 30 \\
\hline Greed by PRESCO management and chief of Oghareki & 20 & 7 \\
\hline Denying Oghareki people the right to fish in the pond inside PRESCO & 70 & 25 \\
\hline Poor communication between the community and PRESCO & 100 & 37 \\
\hline Total & 270 & 100 \\
\hline
\end{tabular}

TABLE 4: Effect of the crisis to the people of the community:

\begin{tabular}{|l|l|l|}
\hline Response & Frequency & $\mathbf{\%}$ \\
\hline Made some people homeless & 100 & 25 \\
\hline Set so many people packing out of the community & 80 & 20 \\
\hline People belonging were looted & 60 & 15 \\
\hline Hatred for PRESCO and its workers & 58 & 15 \\
\hline Some people were dead & 40 & 10 \\
\hline Business at PRESCO closed down & 36 & 9 \\
\hline Plenty of court cases & 20 & 5 \\
\hline No effect & 5 & 1 \\
\hline Total & 399 & 100 \\
\hline
\end{tabular}

TABLE 5: The peace process; parties involved:

\begin{tabular}{|l|l|l|}
\hline Response & Frequency & $\mathbf{\%}$ \\
\hline His Royal Highness & 20 & 10 \\
\hline Government & 10 & 5 \\
\hline Managing Director and the Ovie of Oghareki & 30 & 14 \\
\hline The police force & 40 & 19 \\
\hline $\begin{array}{l}\text { Youth leader, Ovie of Oghareki, Managing Director of PRESCO } \\
\text { and his men and the Nigeria Police }\end{array}$ & 100 & 47 \\
\hline State Attorney General & 10 & 5 \\
\hline Total & 210 & 100 \\
\hline
\end{tabular}

